\title{
Analysis of the Factors Affecting the Accounting Learning Effect of College Students in China
}

\author{
Li-Ling Yang ${ }^{1}$ \\ ${ }^{1}$ Economics \& Management College, Zhaoqing University City526061, Guangdong Province, China \\ Email:2596661416@qq.com
}

\begin{abstract}
Accounting education is very important in China, and there were very few researches on the learning effect of accounting of college students. This paper discusses the factors that influence the learning effect of accounting students from Zhaoqing University School of Economics and Management in China. Through a questionnaire survey, the results indicate that learning motivation and learning attitude have a positive effect on students' learning effect, which is statistically significant. However, the external factors, including teaching quality, class atmosphere and family environment, did not reach the statistically significant level.
\end{abstract}

Keywords: Accounting Learning, External factors, Internal factors, Learning effect

\section{INTRODUCTION}

The achievement of educational goals depends on perfect educational facilities, successful teaching and effective learning. In recent years, Chinese higher education has begun to attach importance to studentcentered comprehensive quality evaluation, from "input" evaluation of teaching conditions to "output" evaluation of teaching effect. This also makes the learning effect of college students become the basic index to measure the quality of college education.

In the field of accounting education, how to improve accounting education has always been a subject of great concern. College education is the cradle of cultivating talents, and the quality of accounting education will directly affect the quality of accounting professionals. Perfect educational facilities, excellent teaching quality and students' love of learning are the keys to a good accounting education.

About social education model has also pointed out that there are four factors affecting the learning result, namely the external factors, individual differences and learning effect, learning scene, in which, fit differences mainly involves the students' interest, motivation, talent, and so on, by contrast, student motivation is the most influential, it is also the key to improve students' learning effects and other factors depend on the existence of the motivation factors.
However, in the past, most of the studies focused on primary and secondary school students, and less on the internal and external factors affecting the learning effect of college students. Therefore, this study, referring to previous studies, discusses the influence of students' internal factors and external environment on the learning performance of accounting.

\section{LITERATURE}

Many studies have a wide range of factors affecting students' learning effect, including testing learning attitude, life, family economic conditions, learning motivation, learning behavior and teacher communication. Chen Yukun (2004) believes that by providing an effective learning environment, students can be more engaged in learning [1]. Liu Yu, and Zhang Aiping (2012) pointed out that the main factors affecting the learning effect of college students are not strong motivation and insufficient social environment support. It is necessary to improve the cognitive level of college students and provide corresponding social and environmental support to improve the learning effect of college students [2].

Taking Tsinghua University undergraduates as an example, Sun Ruijun et al. (2012) found that if academic performance is used as the indicator to measure learning effect, students' source, family economic conditions, learning motivation, learning behavior habits and party membership all have a significant impact on them. However, with self-effect as the measurement index, it is 
found that gender, learning motivation, learning behavior habits, participation and investment in the second class, and communication with teachers have more significant effects [3]. In the digital age, the use of digital learning technology by teachers in learning content can enhance students' learning motivation and learning results [4].

The quality of teachers may be related to improvement student performance [5]. Shen Chao and He Xiumei (2014) discussed the influence of group learning behaviors of college students on learning effect. The research showed that the structure of learning network significantly affects learning effect, and the more frequent the network communication, the higher the overall effect [6].

Liu Xiaoqun and Geng Deying (2005) investigated 1,350 college students, and the results showed that there was a significant correlation between internal motivation and academic performance of college students, while external motivation was negatively correlated with academic performance, that is, too strong external motivation would have a negative effect on academic performance [7]. Tu et al.,(2020) showed that there was a positive correlation between motivation and learning effect [8]. Chen Yufang (2006) pointed out that students' learning satisfaction would affect their learning effect [9]

\section{RESEARCH METHODOLOGY}

\subsection{Research Models}

This study establishes the following empirical model. The dependent variable is learning effect(LE); There are two explanatory variables, including learning environment variable and learning behavior variable. Learning environment variables include three dimensions: teaching quality(TQ), family environment(FE), and class atmosphere(CA). There are two dimensions of learning behavior variables: learning motivation (LM) and learning attitude (LA).Control variables are gender and profession.

$$
\begin{aligned}
\mathrm{LE}= & \alpha_{0}+\beta_{1} T Q+\beta_{2} F E+\beta_{3} C A+\beta_{4} L M+ \\
& \beta_{5} L A+\beta_{6} \text { Gen. }+\beta_{7} \operatorname{Pr} o .+\varepsilon
\end{aligned}
$$

\subsection{Data Source and Variable Definition}

In this study,260 questionnaires were distributed, 252 were recovered and 8 invalid questionnaires were eliminated. The effective recovery rate was $93.8 \%$. Each question is measured by Likert five-point scale. The questionnaire had a 1 point strongly disagree and a 5 point strongly agree. The sample distribution was $33.2 \%$ for boys and $66.8 \%$ for girls.

According to the statistical analysis of major departments, accounting accounted for $17.2 \%$ of the total sample; Investment majors accounted for $14.3 \%$ of the total sample; Human resources majors accounted for $15.6 \%$ of the total sample; International trade majors accounted for $17.6 \%$ of the total sample; Marketing majors accounted for $16.0 \%$ of the total sample; Ecommerce majors account for $19.3 \%$ of the total sample.

\subsubsection{The Learning Environment}

The Likert5-point scale was used to measure teaching quality, family environment and class atmosphere. The higher the score, the more significant the influence on learning effect. The lower the score, the lower the influence. As shown in table 1.

\begin{tabular}{|c|c|}
\hline Construct & Item \\
\hline $\begin{array}{c}\text { Teaching } \\
\text { Quality }\end{array}$ & $\begin{array}{l}\text { 1.I think accounting teachers have } \\
\text { rich professional knowledge. } \\
\text { 2.My accounting teacher is very } \\
\text { enthusiastic in teaching. } \\
\text { 3.Accounting teaching is well- } \\
\text { organized and logical. } \\
\text { 4.Accounting courses generally } \\
\text { provide exercises or assignments at } \\
\text { any time. } \\
\text { 5. The teacher will remind the key } \\
\text { points in class. } \\
\text { 6. The teacher has a solid teaching } \\
\text { content. }\end{array}$ \\
\hline $\begin{array}{c}\text { Family } \\
\text { Environment }\end{array}$ & $\begin{array}{l}\text { 1.Parents have a good comment on } \\
\text { my major. } \\
\text { 2.My parents attach great } \\
\text { importance to my study. } \\
\text { 3. Home will provide a good learning } \\
\text { environment. }\end{array}$ \\
\hline $\begin{array}{c}\text { Class } \\
\text { Atmosphere }\end{array}$ & $\begin{array}{l}\text { 1.Accounting courses are generally } \\
\text { enjoyed by students in the class. } \\
\text { 2.In class, students generally listen } \\
\text { attentively. } \\
\text { 3. Students generally come and go } \\
\text { from class on time. } \\
\text { 4.Students will help each other in } \\
\text { accounting study. } \\
\text { 5. The students in the class generally } \\
\text { only required a pass or a pass. }\end{array}$ \\
\hline
\end{tabular}

Table 1. Learning environment scale

\subsubsection{The Learning Behavior}

The Likert5-point scale was used to distinguish the two dimensions of learning motivation and learning attitude. The higher the score, the more significant the influence on learning effect. The lower the score, the lower the influence. As shown in table 2.

Table 2. Learning behavior scale

\begin{tabular}{c|l}
\hline Construct & \multicolumn{1}{c}{ Item } \\
\hline & $\begin{array}{l}1 . I \text { think learning accounting well } \\
\text { can help me acquire some skills }\end{array}$ \\
aearning & and find a better job in the future. \\
Motivation & $\begin{array}{l}\text { 2.I think accounting is a practical } \\
\text { subject. }\end{array}$
\end{tabular}




\begin{tabular}{c|l} 
& $\begin{array}{l}\text { 3.Accounting can be applied in our } \\
\text { daily life. }\end{array}$ \\
\hline & $\begin{array}{l}\text { 1.I will finish the assignments } \\
\text { assigned in class on time. } \\
2 . I \text { will review the lessons after } \\
\text { class. }\end{array}$ \\
Attitude & $\begin{array}{l}\text { 3. When I encounter problems in } \\
\text { class, I will seek help from my } \\
\text { teachers or classmates. } \\
\text { 4.I will pay attention to the teacher } \\
\text { in class. } \\
\text { 5.I will go to and from class on } \\
\text { time. I won't be late or leave early. }\end{array}$ \\
\hline
\end{tabular}

\subsubsection{The Learning Effect}

The self-evaluation of the learning effect of accounting is measured by Likert 5-point scale. The higher the score is, the more significant the self-cognition degree of learning effect. As shown in table 3.

Table 3. Learning effect scale

\begin{tabular}{c|l}
\hline Construct & \multicolumn{1}{c}{ Item } \\
\hline & $\begin{array}{l}1 . \text { I have a clear understanding of } \\
\text { the accounting courses. } \\
2 . I ' m \text { sure my knowledge of } \\
\text { accounting is accumulating. } \\
\text { Learning } \\
\text { effect } \\
\text { class. did well in accounting in my } \\
4 . I \text { believe I can learn accounting } \\
\text { well. } \\
5 . \text { I think it's the right choice to } \\
\text { study accounting. }\end{array}$ \\
\hline
\end{tabular}

\subsection{Reliability and Validity Analysis of the Scale}

The average teaching quality,family environment, class atmosphere, learning motivation, learning attitude, learning effect were 4.229, 3.853, 3.673, 3.970, 3.916, 3.688 , respectively.

The scale reliability analysis, teaching quality, family environment, class atmosphere, learning motivation, learning attitude, learning effect. The Cronbach's $\alpha$ of the six dimensions are $0.867,0.626,0.632,0.693,0.698$, 0.586 , respectively. In other words, the reliability of the scale is satisfactory.

The KMO value of the total scale was 0.883 , and the Bartlett spherical test $\mathrm{P}<0.001$, which reached $5 \%$ significant level, indicating that each item had good differential validity. The cumulative contribution rate of the structure surface is $59.23 \%$, more than $50 \%$, and the first factor is $31.85 \%$, which is lower than $50 \%$, which indicates that the structural validity of the scale is good.

\section{EMPIRICAL RESULTS}

\subsection{Pearson Correlation Analysis}

Table 4 Pearson correlation analysis shows that, teaching quality (TQ), family environment (FE), class atmosphere (CA), learning motivation (LM), learning attitude (LA) were statistically significantly correlated with learning effect.

Table 4. Pearson correlation analysis

\begin{tabular}{l|llllll}
\hline & \multicolumn{1}{l}{ TQ } & FE & CA & LM & LA & LE \\
\hline TQ & 1 & & & & & \\
FE & $.405^{* *}$ & 1 & & & & \\
CA & $.511^{* *}$ & $.456^{* *}$ & 1 & & & \\
LM & $.429^{* *}$ & $.316^{* *}$ & $.445^{* *}$ & 1 & & \\
LA & $.588^{* *}$ & $.484^{* *}$ & $.561^{* *}$ & $.476^{* *}$ & 1 & \\
LE & $.372^{* *}$ & $.335^{* *}$ & $.370^{* *}$ & $.441^{* *}$ & $.495^{* *}$ & 1 \\
\hline
\end{tabular}

\subsection{Regression Analysis}

Table 5 regression results showed that the internal factors affecting learning effect reached a statistically significant level, including students' learning motivation $(\beta=0.214, P<.000)$; learning attitudes $(\beta=0.309, P<.000)$ The stronger the learning motivation, the higher the learning effect, the better the learning attitude and the better the learning effect.

However, the external factors affecting learning effect, including teaching quality, class atmosphere and family environment, did not reach a statistically significant level. In other words, teaching quality, class atmosphere and family environment are not important factors affecting students' learning effect in this study.

Table 5. Regression analysis of learning environment and learning behavior on learning effect

\begin{tabular}{l|cc}
\hline & \multicolumn{2}{|c}{$\begin{array}{c}\text { Dependent Variable } \\
\text { Learning Effect }\end{array}$} \\
\hline $\begin{array}{l}\text { Explanatory } \\
\text { Variables }\end{array}$ & Model 1 & Model 2 \\
\hline Step 1 & -.071 & -.105 \\
Gender & $-.296^{* * *}$ & $-.152^{* *}$ \\
Professional & & \\
Step 2 & & .004 \\
Teaching Quality & & .086 \\
Family Environment & & .033 \\
Class Atmosphere & & $.214^{* * *}$ \\
Learning Motivation & & $.309^{* * *}$ \\
Learning Attitude & & 0.316 \\
Adj.R & & $17.020^{* * *}$ \\
F & 0.079 & \\
\hline
\end{tabular}

\section{CONCLUSIONS}

This study explores the internal and external factors that influence learning effect. The results showed that 
students generally gave higher evaluation on teachers' teaching quality and attitude, indicating that students believed that teachers had rich professional knowledge and high teaching enthusiasm; in the family environment, some students did not get the support of parents and good evaluation of their major; in the class atmosphere, most students did not highly affirm the class atmosphere and the degree of concentration of class students in class. In terms of learning motivation, students generally think that learning a major well will help them find a job in the future. But in the classroom often do not concentrate and in the class will not actively review the content of the class, lack of positive learning attitude.

According to the results of regression analysis in this study, the internal factors affecting learning effect, students' learning motivation and attitude reached a significant level of statistical results, while the external factors, as teaching quality, class atmosphere and family environment did not reach a statistically significant level. These factors may be very important for primary and middle school students, but for mature college students, external factors no longer have a great influence.

The results of this paper can be provided to the school for reference, and teachers should be encouraged to stimulate and encourage students, such as tutoring students to understand the future development of the subject, in order to improve students' learning motivation. Teachers should pay more attention to students' learning attitude, whether students will finish the assigned homework on time, review the contents of the class after class, and seek the help of teachers or classmates when they encounter difficult problems in class.

This study suggests that follow-up researchers can expand the object and scope of investigation and better understand learning effect of higher education students.

\section{REFERENCES}

[1] Chen Yukun. Introduction to the quality assurance system of higher education. Beijing normal University Press ,2004.

[2] Liu Yu, and Zhang Aiping. An Analysis of the Influencing Factors of College Freshmen Taking Xi'an Jiaotong University as an Example. Journal of University Counselors ,2012.

[3] Sun Ruijun, Shen Ruomeng, and Guan Liu Si. A study on the influencing factors of College students' Learning effect. Journal of the National Institute of Education Administration 9,2012:65-71.

[4] Yonghui Li, Learning Motivation, Learning Strategies and Learning effect: A Case Study of ELearning. Journal of Business Management, No.14, 2017.
[5] Darling-Hammond,Linda. Teacher quality and student achievement. Education policy analysis archives 8,2000: 1 .

[6] Shen Chao and he Xiumei. A study on the influence of group learning behavior on learning effect of college students. PhD Thesis 2014.

[7] Liu Xiaoqun, Geng Deying. A study on the relationship between College students' Learning motivation and academic performance. Journal of Xichang University 17(2), 2005,:75-77.

[8] Tu,Jui-Che and Ku-Hsi Chu. Analyzing the Relevance of Peer Relationship, Learning Motivation, and Learning effect-Design Students as an example. Sustainability,2020.

[9] Chen Yufang ." Discussion on Swimming Status of Senior Pupils in West Lake Primary School in Neihu District, Taipei City." State Education New knowledge,2006,27-35. 